\title{
Characteristics of Wastes Produced by Polish Ferrous Alloys Casting Foundries between the Years 2010-2014
}

\author{
Mateusz Skrzyński* (iD \\ AGH University of Science and Technology, Faculty of Foundry Engineering, Reymonta St. 23, 30-059 Krakow, Poland \\ *e-mail: mskrzyns@agh.edu.pl
}

(C) 2019 Author. This is an open access publication, which can be used, distributed and reproduced in any medium according to the Creative Commons CC-BY 4.0 License requiring that the original work has been properly cited.

Received: 12 December 2019/Accepted: 15 January 2020/ Published online: 31 January 2020

This article is published with open access at AGH University of Science and Technology Press

\begin{abstract}
The balance of wastes originating from the foundry processes of ferrous alloys, prepared on the basis of data made available by the Polish Central Statistical Office, is presented in this paper. The kind and amount of individual foundry wastes subjected to management and storage by foundry plants were analysed. The problem of wastes between the years 2010-2016 is discussed on the national scale, as well as in individual regions or voivodeships. Altogether, 27,375.9 tons of waste from the group no. 10, of which non-ferrous metal and ferrous alloy wastes from foundry plants constituted $2 \%$, were produced in Poland in 2010. This situation remained at a similar level over successive years, till 2014. The positive prognosis constitutes the fact that the amount of waste stored on dumping grounds belonging to foundry plants in Poland is gradually decreasing. This may be related to increasing costs of waste storage. During the tested years, the annual amount of gathered waste decreased from 4,796.6 thousand tons (in 2010) to 4,477.6 thousand tons (in 2014).
\end{abstract}

\section{Keywords:}

spent foundry sands, casting wastes, environment protection

\section{INTRODUCTION}

Founding is an efficient technique of manufacturing metal products with a specific shape and properties. It is based on filling the casting mold of the product with an alloy. Unfortunately, it belongs to the group of technologies which carry with them an increased occupational risk. Employees are exposed to harmful factors caused, among others, by the emission of harmful substances [1-4] during the process. The highest level of harmful substance emissions occurs during the pouring of disposable forms with iron alloys with a high melting temperature $[5,6]$. In this case, one uses sand molds with sand grains connected by a binder. When filling the mold with liquid metal, a part of the binder burns out. Depending on the type of resin used, compounds from the BTEX group may be formed, such as benzene, toluene ethylbenzene, o-, m-, p-xylene), formaldehyde furfuryl alcohol phenol or polycyclic aromatic hydrocarbons (PAH) [7-9].

For the production of non-ferrous castings of zinc, aluminum, magnesium and copper alloys for the process, high pressure machines are more often used and the filled permanent mold is used to make a large number of castings. In this case, the amount of dangerous compounds generated during the foundry process is significantly reduced, together with the amount of waste generated [10].

The second important factor related to the topic of the article, and at the same time a challenge in terms of environmental protection for all foundry technologies, is the amount of waste generated during the production of castings.

Waste materials considered in the paper include:

- spent foundry and core sands,

- slag from the melting processes of liquid metals,

- dusts from cleaning out the furnaces for metal melting,

- other wastes generated during process the casting production process.

In Poland, as of 2014, there has been a change in the approach to the classification of waste generated and the separation of the method of managing this waste as transferred to other recipients. Therefore, the data concerning wastes produced and neutralised or subjected to the reclamation process in 2014, is not comparable with the data from previous years. From this year onwards, waste which is managed by its producers are counted as reclaimed and harmless wastes. 


\section{ANALYSIS OF THE AMOUNTS OF WASTE}

Amounts of produced wastes and their management constitutes an important aspect in casting production. As sources estimate [2], for 1 ton of casting, approximately 1 ton of waste - requiring recycling or storage in special dumping grounds - is produced.

The main wastes at casting productions are wastes from moulds and cores [11-19], which on average constitute $77 \%$ of all wastes $[20,21]$. A diagram presenting the percentages of various wastes from foundry processes is shown in Figure 1.

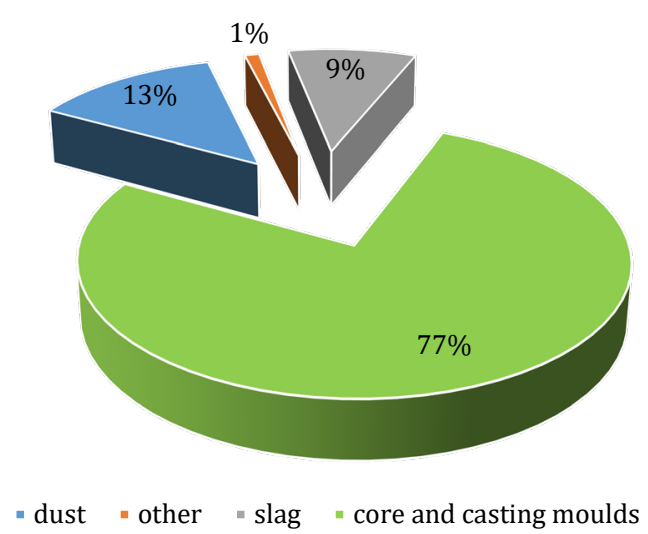

Fig. 1. Amount of waste from foundry processes in 2016 (in percent) [21]

Altogether 27375.9 thousand tons of wastes from the group no. 10 were produced in Poland in 2010. $2 \%$ of these wastes constituted wastes from non-ferrous metals and ferrous alloys castings. This situation remained at a similar level up to the year 2016. Figure 2 presents the amount of waste produced by non-ferrous metal and ferrous alloys castings between the years 2010-2016.

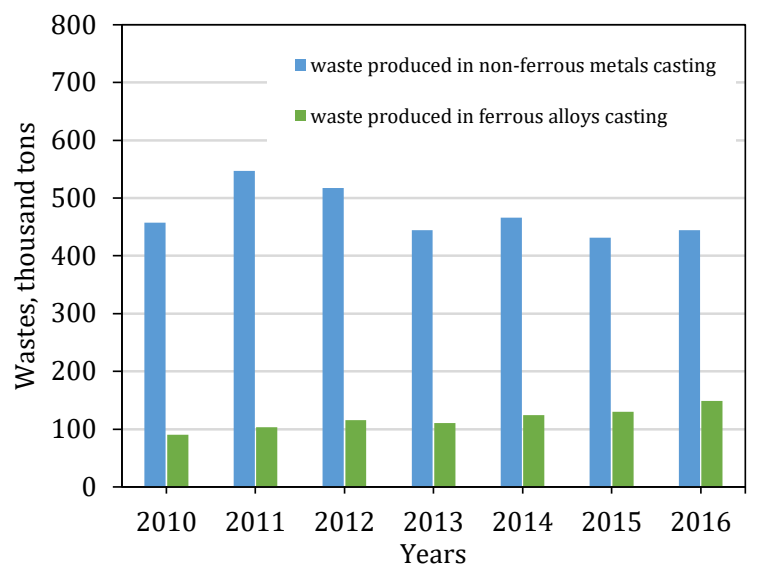

Fig. 2. Waste production by non-ferrous metal and ferrous alloys castings between the years 2010-2016 [21]

According to the report of the Polish Central Statistical Office, the production of waste from ferrous alloys casting in the analyzed years amounted to an average of 595.768 thousand tons and constituted the main source of waste. The amounts of waste originating from non-ferrous metal castings increased slightly during this period.

The largest amounts of waste in Poland were produced in the Silesian, Lesser Poland, Greater Poland and Warmian-Masurian voivodeships. The list of the amount of waste by individual voivodeships is presented in Table 1.

Table 1

List of waste produced by ferrous alloys casting in individual voivodeships in 2016 [22-28]

\begin{tabular}{|c|c|c|c|c|c|c|c|}
\hline \multirow{2}{*}{ Voivodeship } & \multicolumn{7}{|c|}{ Year } \\
\hline & 2010 & 2011 & 2012 & 2013 & 2014 & 2015 & 2016 \\
\hline Silesian & 107.2 & 137.8 & 156.9 & 123.7 & 129.8 & 80.0 & 140.3 \\
\hline Lesser Poland & 82.7 & 94.2 & 68.1 & 63.1 & 57.8 & 57.7 & 57.6 \\
\hline Greater Poland & 77.9 & 97.5 & 96.7 & 67.6 & 70.6 & 55.7 & 53.0 \\
\hline Warmian-Masurian & 68.4 & 65.2 & 63 & 55.7 & 76 & 63.5 & 67.8 \\
\hline Lower Silesian & 24.6 & 28.6 & 28.1 & 35.4 & 36.7 & 67.5 & 21.0 \\
\hline Subcarpathian & 20.5 & 25.1 & 21.7 & 19.8 & 20.1 & 26.0 & 23.5 \\
\hline Lodz & 17.6 & 31.1 & 30.5 & 25.8 & 21.5 & 23.7 & 21.3 \\
\hline Holy Cross & 15.8 & 14.7 & 14.1 & 23 & 25 & 23.5 & 24.7 \\
\hline Masovian & 10.9 & 11.2 & - & - & - & - & - \\
\hline Opole & 8.8 & 21.1 & 12.4 & 5.7 & 6.3 & 7.7 & 9.7 \\
\hline Lubusz & 7.6 & 7.1 & 7.3 & 9.1 & 9.7 & 10.3 & 10.2 \\
\hline Lublin & 7.2 & 4.2 & 10.7 & 8.2 & 5 & 8.0 & 9.1 \\
\hline Kuyavian-Pomeranian & 5.1 & 7 & 6 & 5.8 & 5.8 & 5.4 & 4.7 \\
\hline Pomeranian & 2.1 & 1.8 & 1.5 & 2.6 & 1.6 & 1.5 & 1.3 \\
\hline Podlaskie & 0.9 & 0.7 & 0.6 & - & - & 26.0 & - \\
\hline West Pomerania & - & - & - & - & - & - & - \\
\hline
\end{tabular}


The largest amount of waste was produced in the years 2011 and 2012 [22, 23]. These data, combined with the casting production, are shown in Figure 3.

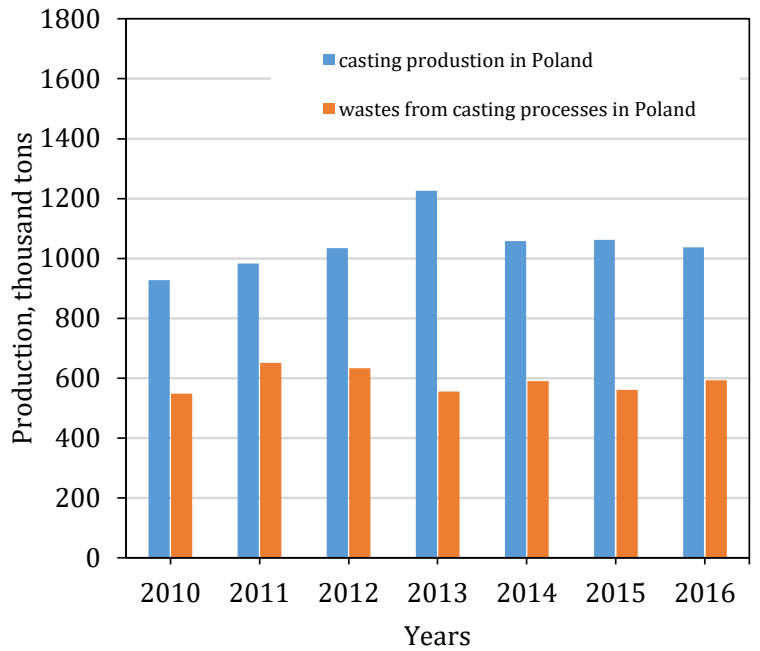

Fig. 3. The compilation of the casting production and the amount of waste related to this production between the years 2010-2016 [22-28]

The highest amounts of foundry wastes were reclaimed in 2016 in the Warmian-Masurian voivodeship and amounted to 50.8 thousand tons, or more than $75 \%$ of the total for the voivodeship. By comparison, Lesser Poland subjected $62 \%$ to reclamation, Silesia only $25 \%$ and Greater Poland only $1 \%$. The total data are given in Figure 4 . Foundry plants in the latter voivodeship had the largest amounts of wastes stored in their own dumping grounds, which in 2010 amounted to 1846.2 thousand tons. Very similar amounts were collected by foundry plants in the Opole voivodeship (1848.1 thousand tons). Between the years 2010-2016, the situation in these two voivodeships was at the similar level and in 2016 it was 1673.5 and 1243.6 thousand tons, respectively. The situation for 2016 is presented in Figure 5.

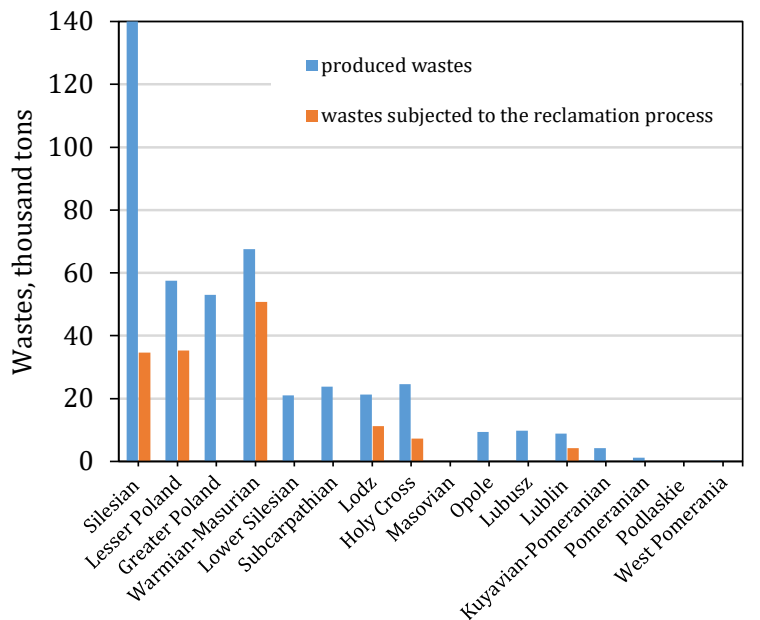

Voivodeship

Fig. 4. The distribution of wastes produced and subjected to reclamation in individual voivodeships in 2016 [21]

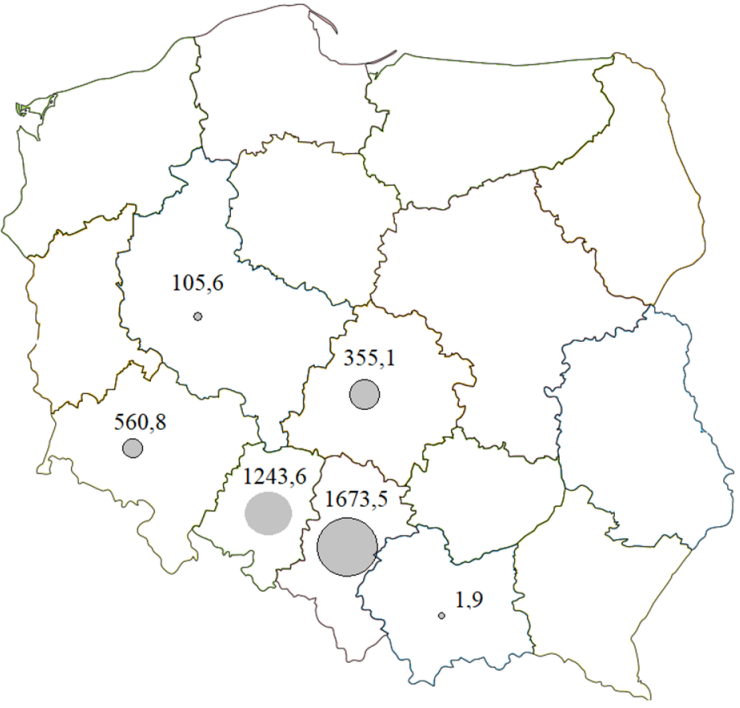

Fig. 5. Wastes (with the elimination of municipal wastes) - stored thus far (gathered) on own dumping grounds (heaps) of foundry plants in 2016 [thousand tons]

The fact that the amount of waste gathered in the dumping grounds of foundry plants has decreased successively throughout the whole country constitutes a positive prognosis. This may be related to the rapidly escalating costs of waste storage. Within the tested years, the amount of gathered waste (on the national scale) decreased from 4796.6 thousand tons (in 2010) to 3940.5 thousand tons in 2016. In this year, there is no information on neutralized waste (Fig. 6).

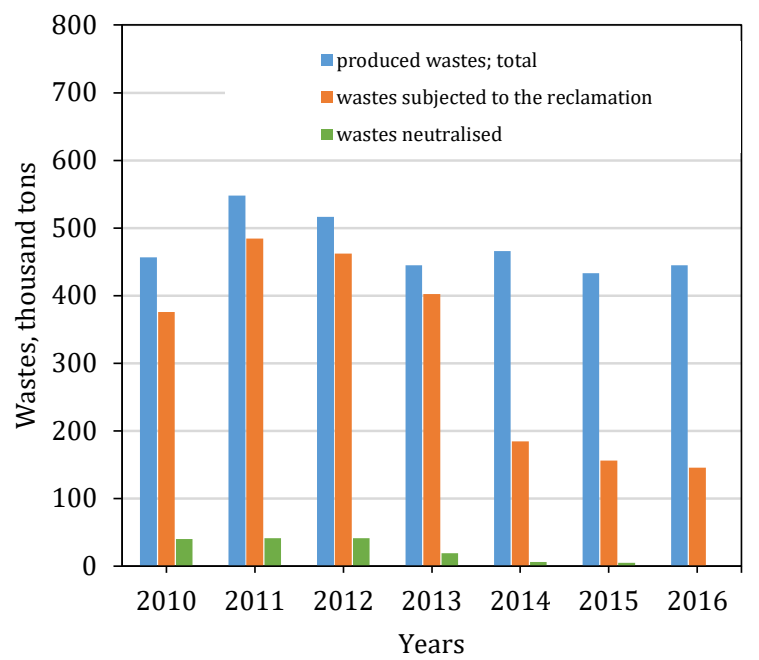

Fig. 6. The compilation of produced wastes, subjected to the reclamation process and neutralised in the period 2010-2016 [21]

Individual groups of wastes produced in the space of the tested years were also analysed. The sequence of their presentation depends on their percentage in the produced wastes.

Apart from the wastes to which spent moulding and core sands belong, there are also wastes originating from the pouring process, marked with code 1009 08. Data gathered up to the year 2013 indicates that the ratio of the amount of produced wastes to those subjected to the reclamation 
process was at a similar level and amounted to 44.7 thousand tons. A regression was observed in 2014 and which remained over subsequent years. The diagrams showing amounts of produced and reclaimed wastes in individual years are presented in Figure 7.

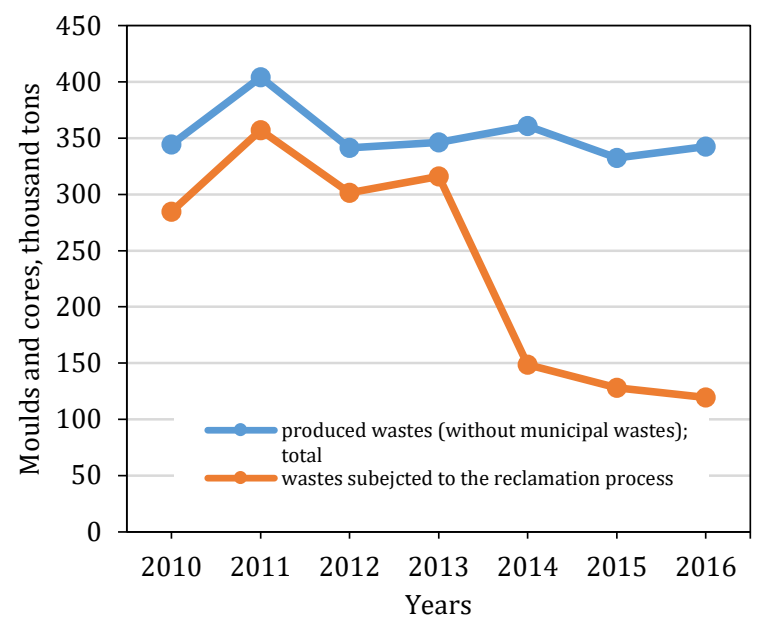

Fig. 7. Listing the amount of waste from the technology of forms and cores in 2010-2016 [21]

In the period studied, it was only in the year 2012 that the production of wastes from the group marked as 1009 07, was revealed. These are cores and moulds after the pouring process containing dangerous substances. All of these wastes were subjected to reclamation procedures. This means that - according to the available data - foundry plants do not have waste in their dumping grounds from the group no. 1009 07. Hazardous wastes gathered by foundry plants are dusts from exhaust gases containing dangerous substances.The amount of this waste, marked by code 100909 , was at a constant level of 1.2 thousand tons during the study period.

On the next places of waste produced by the foundries there are slags and dusts (Figs. 8 and 9). Also in their case, up to the year 2013 a constant difference between produced and reclaimed wastes could be noticed. After this year, there was a significant decrease in the amount of waste recovered.

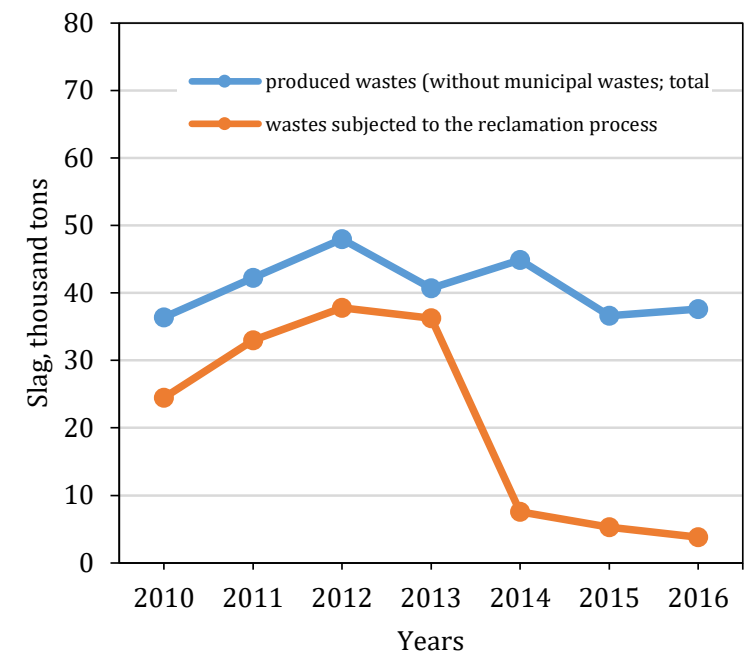

Fig. 8. Slag from the liquid metals melting produced in years 2010-2016 [21]

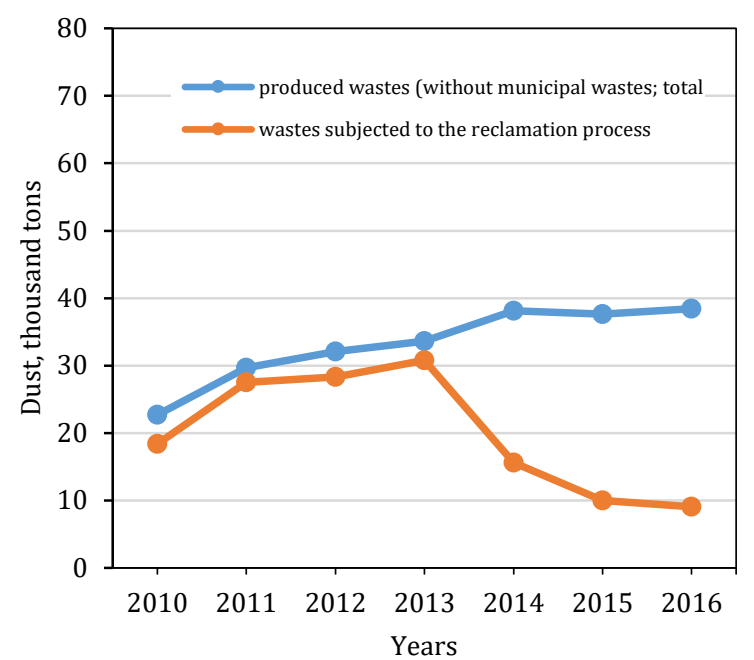

Fig. 9. Dusts from dedusting furnaces for melting liquid metals in years 2010-2016 [21]

\section{CONCLUSIONS}

The following conclusions can be drawn on the basis of the analysis:

- The ratio of the wastes produced during the pouring processes to the wastes subjected to the reclamation processes was at a similar level in years 2010-2013.

- An alarming decrease of waste subjected to reclamation was observed in 2014. However, it could have been caused by a change in the classification method of the waste produced, with it being delivered to other customers and not subjected to reclamation procedures and neutralised.

- In 2014-2016, a further decline in the amount of waste subject to remediation can be observed.

\section{REFERENCES}

[1] Holtzer M., Dańko R., Dańko J., Kubecki M., Bobrowski A. \& Śpiewok W. (2013). Ocena szkodliwości materiałów wiążących stosowanych do mas formierskich i rdzeniowych nowej generacji. Kraków: Wydawnictwo Naukowe Akapit.

[2] Meléndez A., García E., Carnicer P., Pena E. \& Larrión M. (2012). Fine and Ultrafine Emission Dynamics from a Ferrous Foundry Cupola Furnace. Journal of the Air \& Waste Management Association, 60(5), 556-567. doi:10.3155/1047-3289.60.5.556

[3] Maj M., Werrtz J. \& Piekło J. (2017). Environmental Protection Versus Foundry Engineering Practice. Archives of Foundry Engineering, 17(2), 202-206.

[4] Dutouquet C., Gallou G., Le Bihan O., Sirven J. B., Dermigny A., Torralba B. \& Frejafon E. (2014). Monitoring of heavy metal particle emission in the exhaust duct of a foundry using LIBS. Talanta, 127, 75-81. Doi:10.1016/j.talanta.2014.03.063

[5] LaFay V., Neltner S., Carroll D. \& Couture D.J. (2010). Know the Environmental Impact of Your Additives. Modern Casting, 10, 27-29.

[6] Kubecki M. (2016). Oznaczenie wybranych niebezpiecznych zanieczyszczeń powietrza, generowanych $w$ procesie termicznego rozkładu mas formierskich z żywicami furanowymi. Doctoral Dissertation. Polska Akademia Nauk, Oddział Katowice, Komisja Odlewnictwa.

[7] Ribeiro M.G. \& Filho W.R.P. (2006). Risk assessment of chemicals in foundries: The International Chemical Toolkit pilot-project. Journal of Hazardous Materials, 136(3), 432-437. Doi:10.1016/J.JHAZMAT.2006.01.019 
[8] Faber J. \& Perszewska K. (2017). Identification Odor Compounds Emitted During the Heating of Molding Sands. Archives of Foundry Engineering, 17(2), 178-182. Doi:10.1515/ afe-2017-0071

[9] Kubecki M., Holtzer M., Bobrowski A., Dańko R., Grabowska B. \& Żymankowska-Kumon S. (2018). Analysis of the Compounds from the BTEX Group, Emitted During Thermal Decomposition of Alkyd Resin. Archives of Foundry Engineering, 12(3), 69-74. Doi:10.2478/v10266-012-0084-z

[10] Moryson G. (2009). Evaluation classification in the wastes of aluminum and its alloys. Archives of Mechanical Technology and Automation, 29(3), 59-72.

[11] Holtzer M., Dańko R. \& Żymankowska-Kumon S. (2012). Foundry Industry - Current State and Future Development Casting Production. Metalurgija, 51(3), 337-340.

[12] Dańko J., Dańko R. \& Holtzer M. (2003). Reclamation of used sands in foundry production. Metalurgija, 42(3), 173-177.

[13] Pezarski F., Maniowski Z. \& Izdebska-Szanda I. (2004). Praktyczne aspekty procesu regeneracji piasków z zużytych mas formierskich i rdzeniowych. Archiwum Odlewnictwa, 4(13), 171-176.

[14] Łucarz M. (2015). Thermal reclamation of the used moulding sands. Metalurgija, 54(1), 109-112.

[15] Dańko R. (2012). Investigations of the matrix quality in the circulation process of moulding sands with an organic binder. Archives of Foundry Engineering, 12(1), 21-26.

[16] Skrzyński M. \& Dańko R. (2014). Assessment of the Destruction Degree of the Quartz Matrix in the REGMAS Reclaimer. Archives of Foundry Engineering, 14(1), 17-22.

[17] Holtzer M., Dańko R., Żymankowska-Kumon S. \& Kamińska J. (2009). Assessment of the possibility of utilisation of used ceramic moulds originated from the investment casting technology. Archives of Foundry Engineering, 9(2), 159-164.
[18] Joseph M. K., Banganayi F. \& Oyombo D. (2017). Moulding Sand Recycling and Reuse in Small Foundries. Procedia Manufacturing, 7, 86-91. Doi:10.1016/J.PROMFG.2016.12.022

[19] Dańko J., Kamińska J. \& Skrzyński M. (2013). Reclamation of spent moulding sands with inorganic binders in the vibratory reclaimer REGMAS. Archives of Metallurgy and Materials, 58(3), 993-996. Doi:10.2478/amm-2013-0117

[20] Kamińska J. (2013). Analiza wpływu parametrów pracy granulatora misowego na przebieg procesu granul owania pyłów poregeneracyjnych. Doctoral Dissertation, Kraków: Wydział Odlewnictwa University of Science and Technology, Faculty of Foundry Engineering, Krakow.

[21] Waste (excluding municipal waste) by Waste Classification. Statistics Poland. Retrieved from http://swaid.stat.gov.pl/Stan-OchronaSrodowiska_dashboards/Raporty_predefiniowane/ RAP_DBD_SROD_6.aspx

[22] 46th Census of World Casting Production. (2012). Modern Casting, 25-29.

[23] 47th Census of World Casting Production. (2013). Modern Casting, 18-23.

[24] 45th Census of World Casting Production. (2011). Modern Casting, 16-21.

[25] 48th Census of World Casting Production. (2014). Modern Casting, 17-21.

[26] 49th Census of World Casting Production. (2015). Modern Casting, 26-31.

[27] 50th Census of World Casting Production. (2016). Modern Casting, 25-29.

[28] Census of World Casting Production: Global Casting Production Growth Stalls. (2017). Modern Casting, 24-29. 